\title{
Emission of Volatile Organic Compounds After Herbivory from Trifolium pratense (L.) Under Laboratory and Field Conditions
}

\author{
Rose N. Kigathi • Sybille B. Unsicker • \\ Michael Reichelt • Jürgen Kesselmeier • \\ Jonathan Gershenzon • Wolfgang W. Weisser
}

Received: 4 September 2009/Revised: 16 November 2009/Accepted: 18 November 2009/Published online: 15 December 2009

(C) The Author(s) 2009. This article is published with open access at Springerlink.com

\begin{abstract}
Plants emit a wide range of volatile organic compounds in response to damage by herbivores, and many of the compounds have been shown to attract the natural enemies of insect herbivores or serve for inter- and intra-plant communication. Most studies have focused on volatile emission in the laboratory while little is known about emission patterns in the field. We studied the emission of volatiles by Trifolium pratense (red clover) under both laboratory and field conditions. The emission of 24 compounds was quantified in the laboratory, of which eight showed increased emission rates after herbivory by Spodoptera littoralis caterpillars, including $(E)$ - $\beta$-ocimene, the most abundant compound, (Z)- $\beta$-ocimene, linalool, (E)- $\beta$-caryophyllene, $(E, E)$ - $\alpha$-farnesene, 4,8-dimethyl-1,3,7-nonatriene (DMNT), 1-octen-3-ol, and methyl salicylate (MeSA). While most of these compounds have been reported as herbivore-induced
\end{abstract}

Electronic supplementary material The online version of this article (doi:10.1007/s10886-009-9716-3) contains supplementary material, which is available to authorized users.

R. N. Kigathi $(\bowtie) \cdot$ W. W. Weisser

Institute of Ecology, Friedrich-Schiller-University of Jena,

Dornburger Str. 159,

07743 Jena, Germany

e-mail: R.Kigathi@uni-jena.de

R. N. Kigathi · S. B. Unsicker • M. Reichelt · J. Gershenzon

Max Planck Institute of Chemical Ecology,

Department of Biochemistry,

Hans-Knöll Str. 8, 07745 Jena, Germany

J. Kesselmeier

Max Planck Institute for Chemistry,

Biogeochemistry Department,

Joh. J. Becher Weg 27,

55128 Mainz, Germany volatiles from a wide range of plant taxa, 1-octen-3-ol seems to be a characteristic volatile of legumes. In the field, $T$. pratense plants with varying herbivore damage growing in established grassland communities emitted only 13 detectable compounds, and the correlation between herbivore damage and volatile release was more variable than in the laboratory. For example, the emission of $(E)$ - $\beta$-ocimene, $(Z)$ $\beta$-ocimene, and DMNT actually declined with damage, while decanal exhibited increased emission with increasing herbivory. Elevated light and temperature increased the emission of many compounds, but the differences in light and temperature conditions between the laboratory and the field could not account for the differences in emission profiles. Our results indicate that the release of volatiles from T. pratense plants in the field is likely to be influenced by additional biotic and abiotic factors not measured in this study. The elucidation of these factors may be important in understanding the physiological and ecological functions of volatiles in plants.

Keywords Field study · Herbivore induced plant volatiles (HIPV) - Plant defense · Red clover - Volatile organic compounds (VOC)

\section{Introduction}

Plants emit a wide range of volatile organic compounds (VOCs) from flowers, leaves, fruits, and roots into the surrounding atmosphere. Many of these VOCs mediate important interactions between plants and their environment; e.g., they are involved in attracting natural enemies of herbivores (Arimura et al. 2005) or in attracting 
pollinators and seed dispersers (Dudareva et al. 2004). Herbivore-induced plant volatiles (HIPVs) currently are the most intensively studied VOCs in the field of chemical ecology. A wide range of plant species has been shown to emit new VOCs or increased amounts of constitutive VOCs following herbivore damage (Dicke et al. 2003; Unsicker et al. 2009). Nevertheless, whether or not these volatiles are a result of co-evolutionary processes among plants, herbivores, and their natural enemies remains unclear (Holopainen 2004). This is because most studies have been performed on agriculturally important plant species under greenhouse or laboratory conditions, thus making it difficult to derive direct conclusions on the evolutionary role of HIPVs (Arimura et al. 2005). Although greenhouse and laboratory studies provide useful information on individual interactions among plants, herbivores, and natural enemies, they often fail to include various biotic and abiotic stresses that influence volatile production under natural conditions. Plants in the field often are attacked by multiple insect herbivores and diseases at the same time, in contrast to the situation in the laboratory where plant damage is carefully controlled and usually restricted to one attacking species. Abiotic stresses, such as high light and drought also have been shown to influence plant VOC production although these are rarely studied in the laboratory (Gouinguene and Turlings 2002; Blanch et al. 2007). There are only a few studies that report the volatile bouquets for the vegetative parts of naturally growing plants, for instance those on Nicotiana attenuata (Kessler and Baldwin 2001), wild lima bean (Heil 2004), or Solidago altissima (Tooker et al. 2008).

In the present study, we investigated HIPV emission from the legume Trifolium pratense L. (red clover), under both laboratory and field conditions. Red clover is a common forb in many Central European and North American grassland ecosystems. Although it is cultivated as a forage crop and used to increase soil nitrogen in many parts of the world, it remains a common species of natural meadow plant communities (Hoghjensen and Schjoerring 1994; Andrews et al. 2007). The nitrogen-fixing function of nodules found on red clover plays a key role in natural grassland ecosystems where other plant species growing near such legumes benefit from the nitrogen released from root exudates or upon plant death (Spehn et al. 2002; Temperton et al. 2007). Considered one of the key species in grassland ecosystems, red clover provides a useful basis for looking at multiple ecological roles of HIPVs since it is attacked by various herbivores. In cultivated stands, the root borer Hylastinus obscurus (Marsham) and the clover root weevil (Sitona lepidus Gyllenhal) both have been reported to cause extensive damage in pastures (Tapia et al. 2005; Murray et al. 2007). In natural grasslands, the level of damage on $T$. pratense was reported to be affected by multiple factors including plant community biomass, plant species richness, and plant species composition (Scherber et al. 2006; Unsicker et al. 2006).

Early studies on the induced defenses of $T$. pratense focused on defense against pathogens. Several authors showed that $T$. pratense produces various secondary metabolites such as pterocarpanoid phytoalexins and amides in response to fungi (Macfoy and Smith 1979; Mcmurchy and Higgins 1984). Jasmonic acid (JA) was shown to induce the production of caffeoyl DOPA (clovamide) in the roots but not in the shoots of T. pratense (Tebayashi et al. 2000). Later studies focused on the attraction of root herbivores to root volatiles in $T$. pratense from root extracts (Tapia et al. 2007). Other research on the volatile organic compounds of $T$. pratense has used dried or fresh leaf extracts to determine the quality of the hay produced (Figueiredo et al. 2007).

In the present study, we investigated: 1) the VOCs emitted by $T$. pratense under laboratory conditions after caterpillar herbivory and mechanical wounding; 2) the effects of temperature and sampling duration on VOC composition in the laboratory; and 3) the emission of herbivore-induced volatiles under field conditions.

\section{Methods and Materials}

\section{VOC Production of T. pratense Under Laboratory} Conditions

Plants and Insects Ramets of T. pratense were transplanted from the field in April 2007 when plants were still small $(<10 \mathrm{~cm}$ in height). Plants were trimmed back to $3 \mathrm{~cm}$, potted in $16 \mathrm{~cm}$ pots with a mixture of compost soil and sand (2:1), and allowed to grow under greenhouse conditions (day:night temperatures of $22-25^{\circ} \mathrm{C}: 18-20^{\circ} \mathrm{C}, 16 / 8 \mathrm{~h} \mathrm{~L} / \mathrm{D}$ cycle, photosynthetically active radiation ca. $180 \mu \mathrm{mol} \mathrm{m} \mathrm{m}^{-2} \mathrm{~s}^{-1}$, and $30-55 \%$ relative humidity). Measurements of volatiles were performed as soon as plants reached an average height of $15 \mathrm{~cm}$ (14 days after they were trimmed).

Caterpillars of Spodoptera littoralis Boisd (Lepidoptera: Noctuidae), a generalist leaf-chewing herbivore, were hatched from eggs obtained from Syngenta (Basel, Switzerland) and reared on agar-based artificial media (Fontana et al. 2009) at $23-25^{\circ} \mathrm{C}$ with a $16 / 8 \mathrm{~h} \mathrm{~L} / \mathrm{D}$ cycle until they reached the $3 \mathrm{rd}$ instar.

Herbivory and Temperature Manipulations To determine the effect of herbivory on $T$. pratense, we compared volatile emissions of plants damaged by $S$. littoralis to emissions of control plants and plants subjected to mechanical damage. In total, there were 6 treatments: mechanical wounding, herbivore feeding (4 treatments) and a control. Control 
plants were undamaged and not exposed to leaf herbivores prior to the experiment. Mechanical wounding was induced $15 \mathrm{~min}$ before the start of volatile collection using a commercially available fabric pattern wheel (McCloud and Baldwin 1997). Four tracks were made on the leaf lamina parallel to the mid-rib on 4-6 leaves of the plant depending on its size. For the feeding treatments, plants were exposed to three $S$. littoralis larvae previously starved for $8 \mathrm{~h}$ for a period of: a) $30 \mathrm{~min}$; b) $2 \mathrm{~h}$; c) $8 \mathrm{~h}$; and d) $24 \mathrm{~h}$ before the start of volatile collection. The larvae were removed from the plants at the end of each feeding treatment immediately before volatiles were collected.

The effects of temperature on VOC emission were tested by performing experiments at both $20^{\circ} \mathrm{C}$ and at $30^{\circ} \mathrm{C}$. We used three replicates for each temperature-herbivory treatment combinations so that 36 plants were measured in total (6 treatments $\times 2$ temperatures $\times 3$ replicates)

We also were interested in determining the effect of sampling time on volatile detection. Consequently, for each temperature-herbivory treatment combination, three measurements were performed: $15 \mathrm{~min}, 30 \mathrm{~min}$, and $4 \mathrm{~h}$. These sampling time tests were carried out consecutively; entrainment vials were opened at each time point to change the traps. This gave a total of 3 pseudo-replicates per temperature-herbivory combination.

Volatile Collection in the Laboratory VOCs were collected using a dynamic headspace sampling system that was installed in a climate chamber under controlled conditions (70\% relative humidity and $150 \mu \mathrm{mol} \mathrm{m} \mathrm{m}^{-2} \mathrm{~s}^{-1} \mathrm{PAR}$ ) as described previously (Chen et al. 2003). The plants were placed inside 31 glass desiccators (Schott, Jena, Germany). Each desiccator was closed tightly with a glass lid and equipped with a valve through which charcoal-purified air entered the system at $41 \mathrm{~min}^{-1}$. Volatiles were collected from the plants by passing the outlet air through a super-Q filter (containing $50 \mathrm{mg}$ Super-Q absorbent) (Analytical Research Systems, Gainesville, FL, USA) at a rate of $21 \mathrm{~min}^{-1}$; the excess was released through vents at the top of the glass jars. VOCs from $6 T$. pratense plants were collected simultaneously in the volatile collection chamber. Replicates were made on different days but at the same time of day, from 0900 to $1500 \mathrm{~h}$. After each collection, the volatiles were eluted from the traps with $150 \mu \mathrm{l}$ hexane and $10 \mu \mathrm{l}$ of an internal standard (n-nonylacetate; SigmaAldrich, Seelze, Germany) at a concentration of $4 \mathrm{ng} \mu \mathrm{l}^{-1}$. At the end of each VOC collection, the leaves per plant were counted and percent herbivory was estimated.

Volatile Analysis Sample analysis was conducted using an Agilent 6890 Series gas chromatograph, with helium as the carrier gas; the outlet of the column (DB-5MS $30 \mathrm{~m} \times$ $0.25 \mathrm{~mm} \times 0.25 \mu \mathrm{m}$ film) was coupled to a mass spectrometer
(Agilent $5973 \mathrm{~N}$ quadrupole detector). Parameters for electron impact sample ionization were as follows: interface temperature, $280^{\circ} \mathrm{C}$; repeller, $30 \mathrm{~V}$; emission, $34.6 \mu \mathrm{A}$; electron energy, $70 \mathrm{eV}$; source temperature, $230^{\circ} \mathrm{C}$. The gas chromatographic conditions were as follows: splitless injection at $220^{\circ} \mathrm{C}$, initial oven temperature, $40^{\circ} \mathrm{C}$ for $3 \mathrm{~min}$, increased at $5^{\circ} \mathrm{C} \mathrm{min}^{-1}$ to $210^{\circ} \mathrm{C}$ followed by an increase of $60^{\circ} \mathrm{C} \mathrm{min}^{-1}$ to $300^{\circ} \mathrm{C}$ and held for $2 \mathrm{~min}$. To identify compounds, the mass spectra were compared with those in the commercially available mass spectra libraries NIST and Wiley. Individual compounds were quantified by calculating the peak area relative to the peak area for the internal standard. Reference factors were determined using a mixture of pure standards (where available, see Tables 1, 2 and 3). For statistical analysis, all volatile emissions were standardized to the amount of compounds released per leaf (ng leaf ${ }^{-1} \mathrm{~h}^{-1}$ ). Dry weight (DW) of leaves of T. pratense was in later experiments found to range between $0.01-0.04 \mathrm{~g}_{\text {leaf }}{ }^{-1}$.

\section{VOC Production of T. pratense Under Field Conditions}

Design of Field Sampling Field measurements were carried out in plots of "The Jena Experiment" (a long term grassland biodiversity experiment established in 2002 in Jena, Germany; for details, see Roscher et al. 2004). The plant communities were established from seeds in 2002 from a pool of nine plant species (the so-called dominance experiment, Roscher et al. 2004): Trifolium pratense, Trifolium repens, Anthriscus sylvestris, Geranium pratense, Alopecurus pratensis, Arrhenatherum elatius, Dactylis glomerata, Phleum pratense, and Poa trivialis. Plant species composition has been maintained by weeding since the establishment of the plots in 2002. We randomly selected seven $3.5 \times 3.5 \mathrm{~m}$ plots, all with three-species mixtures, in which to perform plant volatile measurements on the target species, $T$. pratense. Two $T$. pratense plants were selected from each plot, one with high levels of leaf herbivory (based on a visual estimate of leaf area loss due to chewing insects) and one with low levels of herbivory. VOCs from both plants were collected simultaneously, after which the plants were harvested and the leaf area consumed by herbivores was immediately assessed visually on five randomly selected leaves per plant to the nearest $5 \%$ for each leaflet. The mean percent damage value of the 5 leaves was used as the percent damage of the plant for further analysis. Finally, leaf dry weight was determined after plants were dried for $48 \mathrm{~h}$ at $70^{\circ} \mathrm{C}$.

Volatile Collection and Analysis The volatile collection consisted of a push-pull system (Tholl et al. 2006). Plants in the field were enclosed in a $30 \times 50 \mathrm{~cm}$ polyethylene terephthalate (PET) cooking bag (Toppits ${ }^{\circledR}$ Bratschlauch, 
Table 1 Volatile emission from Trifolium pratense in the laboratory experiment (mean \pm SE amount, ng leaf ${ }^{-1} \mathrm{~h}^{-1}$ ) emitted after 4 hours of sampling at $20^{\circ} \mathrm{C}$

\begin{tabular}{|c|c|c|c|c|c|c|}
\hline \multirow[t]{2}{*}{ Compounds } & \multirow[t]{2}{*}{ Control } & \multirow[t]{2}{*}{ Mechanical Wounding } & \multicolumn{4}{|c|}{ Herbivory treatments } \\
\hline & & & $30 \mathrm{~min}$ & $2 \mathrm{~h}$ & $8 \mathrm{~h}$ & $24 \mathrm{~h}$ \\
\hline$\alpha$-Pinene ${ }^{d}$ & $0.11 \pm 0.11$ & $0.07 \pm 0.07$ & $0.11 \pm 0.11$ & $0.16 \pm 0.16$ & $0.08 \pm 0.08$ & - \\
\hline Sabinene $^{\mathrm{d}}$ & $0.04 \pm 0.04$ & - & $0.1 \pm 0.1$ & - & - & - \\
\hline$\beta$-Pinene ${ }^{\mathrm{d}}$ & $0.09 \pm 0.09$ & $0.1 \pm 0.1$ & - & $0.27 \pm 0.27$ & - & - \\
\hline Limonene ${ }^{* \mathrm{~d}}$ & $0.11 \pm 0.11$ & $0.11 \pm 0.11$ & $0.13 \pm 0.09$ & $0.18 \pm 0.18$ & $0.14 \pm 0.07$ & $0.07 \pm 0.07$ \\
\hline 1,8 -Cineole ${ }^{\mathrm{d}}$ & - & - & $0.39 \pm 0.39$ & - & - & - \\
\hline$(Z)-\beta$-Ocimene ${ }^{\mathrm{d}}$ & $--^{\mathbf{a}}$ & $0.38 \pm 0.21^{\mathrm{a}}$ & $0.55 \pm 0.27^{\mathrm{ab}}$ & $1.6 \pm 0.34^{b}$ & $4.11 \pm 2.39^{b}$ & $5.71 \pm 3.13^{b}$ \\
\hline$(E)-\beta$-Ocimene ${ }^{d}$ & $0.06 \pm 0.06^{\mathrm{a}}$ & $1.66 \pm 0.84^{\mathrm{a}}$ & $2.75 \pm 1.19^{\mathrm{a}}$ & $6.93 \pm 1.42^{b}$ & $19.68 \pm 11.19^{b c}$ & $26.21 \pm 12.55^{c}$ \\
\hline Linalool $^{\mathrm{d}}$ & $-{ }^{\mathbf{a}}$ & $-{ }^{\mathbf{a}}$ & $-{ }^{a}$ & $0.36 \pm 0.19^{b}$ & $0.26 \pm 0.26^{b}$ & $1.82 \pm 1.58^{\mathrm{c}}$ \\
\hline Indole & $0.13 \pm 0.13$ & $0.29 \pm 0.29$ & $0.6 \pm 0.36$ & $0.15 \pm 0.15$ & $0.15 \pm 0.07$ & $2.74 \pm 2.67$ \\
\hline$(Z)-$ Jasmone $^{\mathrm{d}}$ & $0.06 \pm 0.06$ & - & - & $0 \pm 0$ & $0.14 \pm 0.14$ & $1.08 \pm 1.08$ \\
\hline$(E)-\beta$-Caryophyllene ${ }^{\mathrm{d}}$ & $-{ }^{\mathbf{a}}$ & $-{ }^{\mathbf{a}}$ & $0.01 \pm 0.01^{b}$ & $0.51 \pm 0.17^{b}$ & $0.38 \pm 0.19^{b}$ & $3.17 \pm 2.49^{\mathrm{b}}$ \\
\hline$(E)-\beta$-Farnesene ${ }^{\mathrm{d}}$ & $0.05 \pm 0.05$ & - & - & $0.1 \pm 0.1$ & $0.31 \pm 0.31$ & - \\
\hline Germacrene D & $0.27 \pm 0.27$ & - & - & - & - & - \\
\hline$(E, E)-\alpha-F a r n e s e n e^{* d}$ & $-{ }^{\mathbf{a}}$ & $0.15 \pm 0.15^{\mathrm{a}}$ & $-^{\mathbf{a}}$ & $-^{\mathbf{a}}$ & $0.12 \pm 0.06^{b}$ & $0.48 \pm 0.28^{b}$ \\
\hline DMNT & $-{ }^{\mathbf{a}}$ & $-^{\mathbf{a b}}$ & $0.51 \pm 0.43^{\mathrm{ab}}$ & $0.47 \pm 0.28^{\mathrm{ab}}$ & $2.88 \pm 2.5 b^{c}$ & $4.14 \pm 2.47^{b c}$ \\
\hline$(Z)-3-H e x e n y l$ acetate $^{\mathrm{d}}$ & - & $0.09 \pm 0.09$ & - & $0.34 \pm 0.34$ & $0.35 \pm 0.17$ & $0.13 \pm 0.13$ \\
\hline 1-Octen-3-ol & $-{ }^{\mathbf{a}}$ & $0.29 \pm 0.29^{\mathrm{a}}$ & $0.2 \pm 0.2^{\mathrm{a}}$ & $0.12 \pm 0.12^{\mathrm{a}}$ & $0.73 \pm 0.57^{b}$ & $0.66 \pm 0.21^{b}$ \\
\hline Benzyl alcohol & $0.31 \pm 0.05$ & - & $0.14 \pm 0.07$ & $0.4 \pm 0.21$ & $0.17 \pm 0.09$ & $0.27 \pm 0.14$ \\
\hline Dodecane & $0.31 \pm 0.06$ & $0.56 \pm 0.21$ & $0.30 \pm 0.08$ & $0.63 \pm 0.11$ & $0.33 \pm 0.08$ & $0.41 \pm 0.1$ \\
\hline Undecane & $0.54 \pm 0.03$ & $1.17 \pm 0.56$ & $0.53 \pm 0.11$ & $0.75 \pm 0.09$ & $0.67 \pm 0.2$ & $0.34 \pm 0.18$ \\
\hline Octylaldehyde & $0.27 \pm 0.05$ & $0.19 \pm 0.19$ & $0.08 \pm 0.08$ & $0.28 \pm 0.28$ & $0.1 \pm 0.1$ & $0.19 \pm 0.12$ \\
\hline Nonanal & $0.68 \pm 0.34$ & $1.33 \pm 0.66$ & $0.75 \pm 0.17$ & $0.96 \pm 0.96$ & $0.38 \pm 0.38$ & $0.86 \pm 0.54$ \\
\hline Decanal & $3.15 \pm 2.14$ & $2.12 \pm 0.79$ & $1.15 \pm 0.47$ & $2.01 \pm 0.89$ & $1.14 \pm 0.49$ & $1.76 \pm 0.79$ \\
\hline MeSA & $-{ }^{\mathbf{a}}$ & $-{ }^{\mathbf{a}}$ & $0.69 \pm 0.38^{\mathrm{a}}$ & $2.48 \pm 1.62^{\mathrm{a}}$ & $0.96 \pm 0.59^{b}$ & $2.75 \pm 1.36^{b}$ \\
\hline Total & $6.45 \pm 2.69^{\mathrm{a}}$ & $8.88 \pm 3.89^{a}$ & $9.29 \pm 3.94^{\mathrm{a}}$ & $19.28 \pm 6.46^{b}$ & $33.12 \pm 17.79^{b}$ & $53.01 \pm 28.59^{b}$ \\
\hline
\end{tabular}

Bold letters represent the herbivore-induced compounds. Means in the same row followed by the same letters are not significantly different from each other $(P<0.05)$. An asterisk $(*)$ designates compounds which increased their emission with temperature $(P<0.05)$

${ }^{\mathrm{d}}$ Compounds identified by comparison to authentic standards

Melitta, Minden, Germany) which is free of detectable amounts of volatiles (Kost and Heil 2005). The bags enclosed 4 stems of the target plant and were supported by a stainless steel rod on their outsides (Fig. 1). Compressed air (compressor: Schneider Druckluft GmbH, Reutlingen, Germany) entered the system after passing through an activated charcoal filter on the lower side of the plant and was pulled out at the top through an adsorbent super-Q filter by using a vacuum pump (Thomas Products, Memmingen, Germany) at the rate of $1.6 \pm 0.51 \mathrm{~min}^{-1}$ for $30 \mathrm{~min}$ (Fig. 1). Before the initiation of volatile sampling, charcoal-filtered clean air was flushed though the collection system for $15 \mathrm{~min}$; this was found to be sufficient in preliminary experiments to remove volatiles resulting from plant handling during the set-up of the enclosure. Umbrellas were employed to provide shade in order to moderate the temperature inside the bags on sunny days. Collections were made at the same time of day starting at $0900 \mathrm{~h}$ and continuing to $1500 \mathrm{~h}$.

Throughout the volatile collection, temperature was measured inside each bag with temperature sensors; mean temperatures ranged from $20^{\circ} \mathrm{C}$ to $30^{\circ} \mathrm{C}$. Radiation and temperature data also were recorded daily at the weather station at the "Jena Experiment" every 10 min. All temperature and light sensors were obtained from Campbell Scientific (Bremen, Germany).

To estimate the light reduction by the umbrellas, light under the umbrella was measured using a solar meter after the VOC sampling had been completed. Measurements were made continuously from 0900 to $1500 \mathrm{~h}$ for 3 consecutive days. The levels of radiation under the umbrella during the actual VOC sampling then were extrapolated by plotting a regression of measurements made under the umbrella to the weather station measurements on these $3 \mathrm{~d}$. The equation 
Table 2 Volatile emission from Trifolium pratense in the laboratory experiment (mean \pm SE amount, ng leaf ${ }^{-1} \mathrm{~h}^{-1}$ ) emitted after 4 hours of sampling at $30^{\circ} \mathrm{C}$

\begin{tabular}{|c|c|c|c|c|c|c|}
\hline \multirow[t]{2}{*}{ Compounds } & \multirow[t]{2}{*}{ Control } & \multirow[t]{2}{*}{ Mechanical Wounding } & \multicolumn{4}{|c|}{ Herbivory treatments } \\
\hline & & & $30 \mathrm{~min}$ & $2 \mathrm{~h}$ & $8 \mathrm{~h}$ & $24 \mathrm{~h}$ \\
\hline$\alpha$-Pinene & - & $0.1 \pm 0.1$ & - & $0.13 \pm 0.13$ & - & $0.19 \pm 0.19$ \\
\hline Sabinene & $0.14 \pm 0.09$ & $0.06 \pm 0.06$ & - & $0.07 \pm 0.07$ & $0.13 \pm 0.13$ & $0.21 \pm 0.21$ \\
\hline$\beta$-Pinene & - & $0.15 \pm 0.09$ & - & $0.09 \pm 0.09$ & $0.16 \pm 0.16$ & $0.21 \pm 0.12$ \\
\hline Limonene* & $0.67 \pm 0.3$ & $0.44 \pm 0.14$ & $0.31 \pm 0.15$ & $0.43 \pm 0.14$ & $0.52 \pm 0.34$ & $0.29 \pm 0.15$ \\
\hline 1,8-Cineole & - & - & - & $0.21 \pm 0.21$ & $0.26 \pm 0.26$ & $0.09 \pm 0.09$ \\
\hline$(Z)$ - $\beta$-Ocimene & $0.22 \pm 0.22^{\mathrm{a}}$ & $0.16 \pm 0.08^{a}$ & $0.76 \pm 0.09^{a b}$ & $3.42 \pm 3.02^{b}$ & $6.17 \pm 3.14^{b}$ & $5.63 \pm 1.5^{b}$ \\
\hline$(E)$ - $\beta$-Ocimene & $1.15 \pm 0.69^{\mathrm{a}}$ & $0.66 \pm 0.26^{\mathrm{a}}$ & $3.66 \pm 0.19^{\mathrm{a}}$ & $15.57 \pm 13.86^{b}$ & $26.55 \pm 11.05^{b c}$ & $26.95 \pm 7.27^{\mathrm{c}}$ \\
\hline Linalool & $0.3 \pm 0.3^{\mathrm{a}}$ & $-{ }^{a}$ & $0.22 \pm 0.12^{\mathrm{a}}$ & $0.16 \pm 0.16^{b}$ & $0.16 \pm 0.09^{b}$ & $0.29 \pm 0.06^{\mathrm{c}}$ \\
\hline Indole & $2.98 \pm 2.16$ & $0.24 \pm 0.14$ & $0.25 \pm 0.25$ & $0.56 \pm 0.14$ & $0.3 \pm 0.18$ & $0.27 \pm 0.27$ \\
\hline (Z)-Jasmone & $0.21 \pm 0.1$ & $0.15 \pm 0.07$ & $0.25 \pm 0.13$ & $0.13 \pm 0.13$ & $0.51 \pm 0.51$ & $0.62 \pm 0.54$ \\
\hline (E)- $\beta$-Caryophyllene & $-{ }^{a}$ & $-{ }^{\mathbf{a}}$ & $0.3 \pm 0.18^{b}$ & $0.6 \pm 0.42^{b}$ & $1.37 \pm 0.42^{\mathrm{b}}$ & $0.62 \pm 0.48^{b}$ \\
\hline (E)- $\beta$-Farnesene & $0.3 \pm 0.3$ & $0.1 \pm 0.1$ & - & $0.16 \pm 0.16$ & $0.47 \pm 0.47$ & $0.3 \pm 0.15$ \\
\hline Germacrene D & - & - & - & $0.08 \pm 0.08$ & $0.05 \pm 0.05$ & $0.32 \pm 0.26$ \\
\hline$(E, E)-\alpha$-Farnesene ${ }^{*}$ & $-{ }^{a}$ & $-{ }^{a}$ & $0.09 \pm 0.09^{b}$ & $0.41 \pm 0.28^{b}$ & $2.02 \pm 0.58^{c}$ & $0.5 \pm 0.3^{b}$ \\
\hline DMNT & $-{ }^{a}$ & $0.09 \pm 0.09^{\mathrm{ab}}$ & $0.34 \pm 0.06^{\mathrm{ab}}$ & $0.17 \pm 0.17^{\mathrm{ab}}$ & $1.63 \pm 0.57^{\mathrm{bc}}$ & $1.18 \pm 0.31^{\mathrm{bc}}$ \\
\hline (Z)-3-Hexenyl acetate & $0.34 \pm 0.18$ & $0.17 \pm 0.17$ & $0.47 \pm 0.14$ & $0.1 \pm 0.1$ & $0.54 \pm 0.37$ & $0.38 \pm 0.24$ \\
\hline 1-Octen-3-ol & $-^{a}$ & $--^{\mathbf{a}}$ & $0.34 \pm 0.19^{\mathrm{a}}$ & $--^{a}$ & $1.07 \pm 0.67^{b}$ & $0.38 \pm 0^{b}$ \\
\hline Benzyl alcohol & $0.52 \pm 0.37$ & $0.09 \pm 0.09$ & $0.12 \pm 0.12$ & - & $0.09 \pm 0.09$ & $0.08 \pm 0.08$ \\
\hline Dodecane & $0.88 \pm 0.44$ & $0.43 \pm 0.12$ & $0.48 \pm 0.19$ & $0.58 \pm 0.13$ & $0.51 \pm 0.11$ & $0.29 \pm 0.16$ \\
\hline Undecane & $0.83 \pm 0.16$ & $0.54 \pm 0.04$ & $0.41 \pm 0.07$ & $0.67 \pm 0.03$ & $0.57 \pm 0.27$ & $0.36 \pm 0.08$ \\
\hline Octylaldehyde & $0.35 \pm 0.17$ & $0.19 \pm 0.19$ & $0.2 \pm 0.1$ & $0.22 \pm 0.11$ & $0.3 \pm 0.09$ & $0.15 \pm 0.07$ \\
\hline Nonanal & $2.37 \pm 0.9$ & $1.19 \pm 0.32$ & $1.44 \pm 0.4$ & $1.46 \pm 0.06$ & $1.48 \pm 0.45$ & $1.15 \pm 0.26$ \\
\hline Nonanal & $2.37 \pm 0.9$ & $1.19 \pm 0.32$ & $1.44 \pm 0.4$ & $1.46 \pm 0.06$ & $1.48 \pm 0.45$ & $1.15 \pm 0.26$ \\
\hline Decanal & $2.54 \pm 0.51$ & $1.57 \pm 0.36$ & $1.89 \pm 0.04$ & $1.83 \pm 0.28$ & $2.09 \pm 0.7$ & $1.34 \pm 0.02$ \\
\hline Decanal & $2.54 \pm 0.51$ & $1.57 \pm 0.36$ & $1.89 \pm 0.04$ & $1.83 \pm 0.28$ & $2.09 \pm 0.7$ & $1.34 \pm 0.02$ \\
\hline MeSA & $0.12 \pm 0.12^{\mathrm{a}}$ & $0.49 \pm 0.49^{\mathrm{a}}$ & $0.48 \pm 0.25^{\mathrm{a}}$ & $0.39 \pm 0.39^{a}$ & $1.86 \pm 0.17^{b}$ & $1.04 \pm 0.61^{b}$ \\
\hline Total & $14.05 \pm 4.58^{\mathrm{a}}$ & $6.84 \pm 0.44^{\mathrm{a}}$ & $12.03 \pm 1.66^{\mathrm{a}}$ & $27.35 \pm 18.97^{b}$ & $48.98 \pm 16.74^{b}$ & $43.16 \pm 9.83^{b}$ \\
\hline
\end{tabular}

Bold letters represent the herbivore-induced compounds. Means in the same row followed by the same letters are not significantly different from each other $(P<0.05)$. An asterisk $(*)$ designates compounds which increased their emission with temperature $(P<0.05)$

was: radiation under umbrella $=130.04+0.045 *$ radiation at weather station. For all analyses, the mean temperature and radiation during each collection interval was used.

\section{Statistical Analysis}

Emission data were log-transformed and analyzed using repeated measures analysis of variance with the open source software R 2.8.1 (http://www.r-project.org/; Crawley 2007). First, the interaction effects of herbivory treatments with temperature and sampling time were tested as main effects with plant as the random effect. The models were simplified to obtain the simplest models with highest explanatory power. Comparisons between feeding treatments were done after model simplification using factor level reduction.
For field data, the effect of radiation, temperature and herbivory were analyzed using a linear regression analysis. The emission data (ng $\mathrm{g}^{-1} \mathrm{~h}^{-1}$ ) were square root transformed because this provided the best normality of errors and constancy of variance (Crawley 2007). DMNT, limonene, and myrcene occurred only a few times and were therefore converted to binomial data and analyzed using a generalized linear model.

For comparisons between the field and the laboratory experiments, proportions (percentages of total amounts) of 10 plant volatiles found to occur in both field and laboratory experiments were used. For the laboratory collections, only data from the $30 \mathrm{~min}$ sampling time were used, as it was similar to the sampling duration in the field study. After a $t$-test was performed to compare the composition of laboratory and field blends, a principal 
Table 3 Volatile emissions of Trifolium pratense under field conditions (mean $\pm \mathrm{SE}$ amount, ng $\mathrm{g}^{-1} \mathrm{~h}^{-1}$ ) of compounds detected under field conditions. Means for 7 plots were calculated separately for two classes of herbivore damage, low and high

\begin{tabular}{|c|c|c|}
\hline & Low damage & High damage \\
\hline \multicolumn{3}{|l|}{ Monoterpenes } \\
\hline$\alpha$-Pinene $^{\mathrm{a}}$ & $2.78 \pm 0.76$ & $2.05 \pm 1.36$ \\
\hline Myrcene $^{\mathrm{a}}$ & $2.13 \pm 1.43$ & - \\
\hline Limonene $^{\mathrm{a}}$ & $1.01 \pm 0.66$ & - \\
\hline$(Z)-\beta$-Ocimene ${ }^{\mathrm{a}}$ & $6.64 \pm 2.62$ & - \\
\hline$(E)-\beta$-Ocimene ${ }^{\mathrm{a}}$ & $23.42 \pm 6.50$ & $5.57 \pm 2.91$ \\
\hline \multicolumn{3}{|l|}{ Homoterpenes } \\
\hline DMNT & $1.77 \pm 0.95$ & - \\
\hline \multicolumn{3}{|l|}{ Esters } \\
\hline$(Z)-3-H e x e n y l$ acetate ${ }^{a}$ & $8.47 \pm 5.01$ & $1.14 \pm 0.72$ \\
\hline \multicolumn{3}{|l|}{ Hydrocarbons } \\
\hline Unknown & $10.05 \pm 2.17$ & $15.97 \pm 4.14$ \\
\hline Undecane & $7.12 \pm 1.06$ & $8.99 \pm 1.45$ \\
\hline Dodecane & $13.59 \pm 3.25$ & $7.99 \pm 3.83$ \\
\hline \multicolumn{3}{|l|}{ Aldehydes } \\
\hline Decanal & $15.06 \pm 7.30$ & $31.34 \pm 6.56$ \\
\hline Nonanal & $11.74 \pm 1.91$ & $3.97 \pm 2.81$ \\
\hline Total & $103.79 \pm 20.52$ & $77.02 \pm 16.11$ \\
\hline
\end{tabular}

${ }^{a}$ Compounds identified by comparison with authentic standards

components analysis (PCA) was carried out to determine the correlations between low damage and high damage classes in the field and laboratory plants using CANOCO 4.5 (Ter Braak and Šmilauer 2002).

\section{Results}

VOC Emission by T. pratense Under Laboratory Conditions From headspace collections of $T$. pratense in the laboratory, 24 volatile compounds were identified by gas chromatographymass spectrometry. The majority were terpenes: eight monoterpenes, four sequiterpenes and the homoterpene 4,8dimethyl-1,3,7-nonatriene (DMNT). The remainder included eight aliphatic compounds and the aromatics, indole, methyl salicylate (MeSA) and benzyl alcohol (Tables 1, 2).

Effect of Herbivory Feeding by S. littoralis resulted in 2$30 \%$ damage on the experimental plants. This herbivory significantly increased both the total amount of volatiles released and the number of volatile compounds emitted (Tables 1,2). A comparison across all treatments showed that herbivore feeding had a significant effect on emission of $(E)$ - $\beta$-ocimene $\left(F_{5,30}=9.09 ; P<0.01\right)$, $(Z)$ - $\beta$-ocimene $\left(F_{5,30}=4.52 ; P<0.01\right)$, DMNT $\left(F_{5,30}=4.75 ; P<0.01\right),(E$,
$E)$ - $\alpha$-farnesene $\left(F_{5,30}=4.00 ; P<0.01\right),(E)$ - $\beta$-caryophyllene $\left(F_{5,30}=2.00 ; P<0.05\right)$, linalool $\left(F_{5,30}=3.07 ; P<0.05\right)$ and MeSA $\left(F_{5,30}=2.72 ; P<0.05\right)$ (Tables 1,2$)$. These seven compounds can, therefore, be considered herbivoreinduced plant volatiles (HIPVs). There was no significant difference in emissions between mechanical wounding and control treatments for the six HIPVs based on factor level reduction (Tables 1, 2). The $30 \mathrm{~min}$ feeding treatment showed an increased emission in total volatiles from the control, but this increase was significantly different for only two specific compounds, $(E)-\beta$-caryophyllene and $(E)-\beta$ ocimene $(P<0.05$, Tables 1,2$)$. Plants exposed to $8 \mathrm{~h}$ and $24 \mathrm{~h}$ feeding emitted the highest amount of ( $Z$ )- $\beta$-ocimene, (E)- $\beta$-ocimene, and DMNT with no significant difference between the two feeding times. However, for $(E, E)-\alpha$ farnesene, emission peaked at $8 \mathrm{~h}$ and then was lower after $24 \mathrm{~h}$ of feeding (Tables 1, 2). For the compounds (Z)- $\beta$ ocimene, MeSA and $(E)-\beta$-caryophyllene, the 2,8 , and $24 \mathrm{~h}$ feeding treatments did not differ significantly in emission (Tables 1, 2).

Effect of Temperature and Sampling Time Across all treatments, temperature had the strongest effect on emission of limonene $\left(F_{1,34}=8.30 ; P<0.01\right)$. The amount of limonene emitted at $30^{\circ} \mathrm{C}$ was higher than that emitted at $20^{\circ} \mathrm{C}(P<$ 0.01 , Fig. 2). Among the herbivore-induced volatiles, only $(E, E)-\alpha$-farnesene emissions increased when temperature increased $\left(F_{1,24}=5.93 ; P<0.05\right)$. There was an interaction between feeding treatment, temperature, and sampling time on the emission of $(E, E)-\alpha$-farnesene $\left(F_{10,48}=4.72 ; P<\right.$ $0.01)$. Emission was higher after the $8 \mathrm{~h}$ feeding at $30^{\circ} \mathrm{C}$ and $4 \mathrm{~h}$ of sampling than after other treatments $(P<0.01$; Tables 1, 2).

Sampling time had an effect on the amounts of the terpenes $\alpha$-pinene $\left(F_{2,70}=4.75 ; P<0.05\right), \beta$-pinene $\left(F_{9,70}=\right.$ 9.33; $P<0.01), 1,8$-cineole $\left(F_{9,70}=3.53 ; P<0.05\right)$, and $(Z)$ -

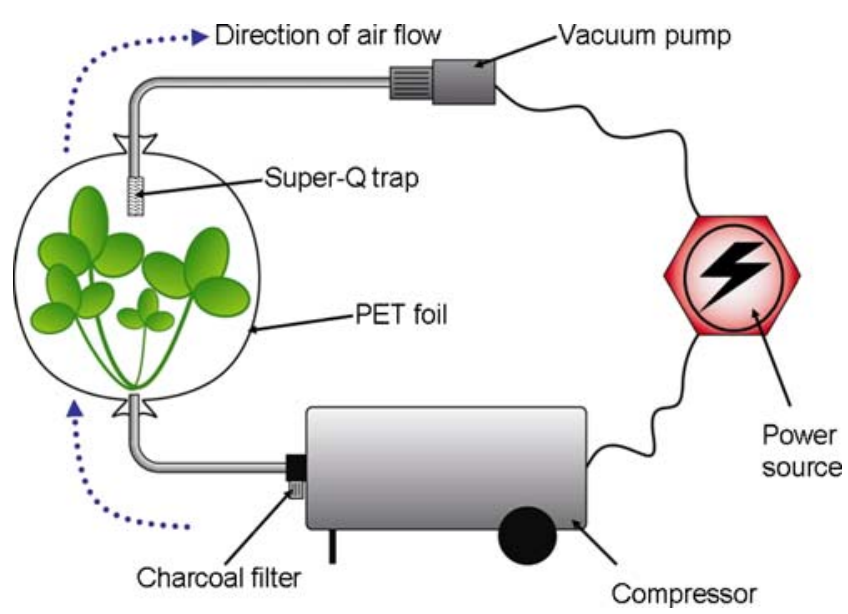

Fig. 1 Diagram of the VOC sampling system used in field collections 


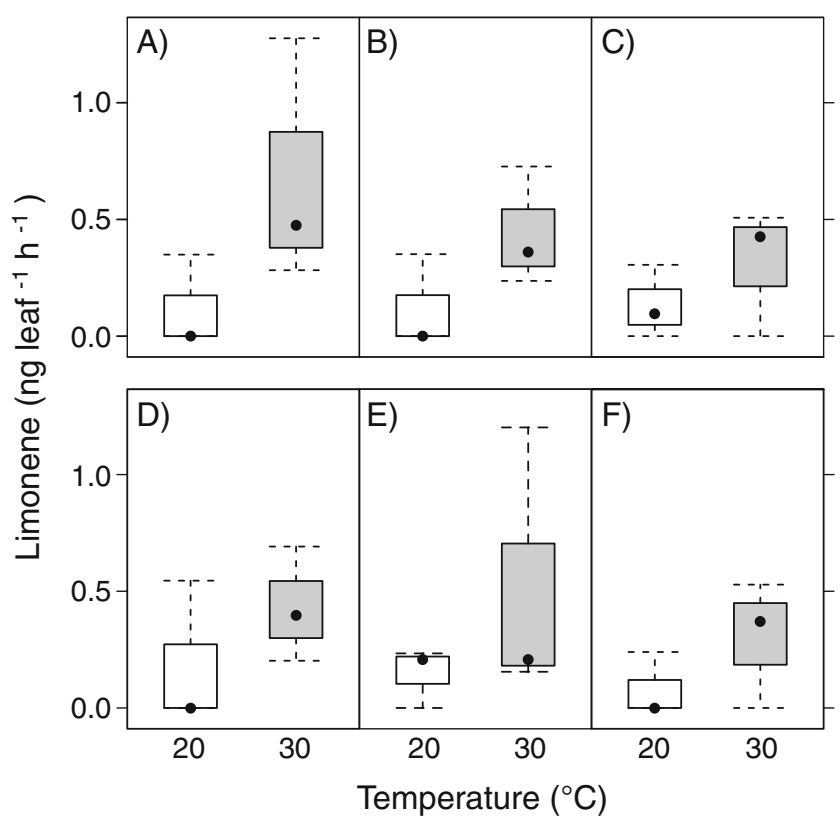

Fig. 2 Effect of temperature on the amount (ng leaf ${ }^{-1} \mathrm{~h}^{-1}$ ) of limonene emitted from Trifolium pratense in the laboratory experiment. Panels show different treatments: (A) control, (B) mechanical wounding, (C) $30 \mathrm{~min}$ feeding, (D) $2 \mathrm{~h}$ feeding, (E) $8 \mathrm{~h}$ feeding, and (F) $24 \mathrm{~h}$ feeding. Dots in the boxes are the median values, while the bottom and top of the box show 25th and 75th percentiles respectively. Dashed vertical lines show either the maximum value or 1.5 times the interquartile range of the data (whichever is smaller). Open boxes depict data for $20^{\circ} \mathrm{C}$ and shaded boxes for $30^{\circ} \mathrm{C}$

jasmone $\left(F_{9,70}=8.35 ; P<0.01\right)$. These compounds were detected only after $4 \mathrm{~h}$ collection. Sampling time also had an interaction effect with feeding treatment on the emission of 1-octen-3-ol $\left(F_{10,60}=2.08 ; P<0.05\right)$ where the effect of herbivory was detected after $4 \mathrm{~h}$, but not after the 15 and 30 min sampling times. Thus, 1-octen-3-ol can also be regarded as an HIPV bringing the total number of such compounds in this study to eight.

The amounts of benzyl alcohol $\left(F_{2,70}=3.00 ; P<0.05\right)$, (Z)3-hexenyl acetate $\left(F_{2,70}=47.4 ; P<0.01\right)$, decanal $\left(F_{2,70}=\right.$ 4.75; $P<0.05)$, dodecane $\left(F_{2,70}=3.7 ; P<0.02\right)$ and undecane $\left(F_{2,68}=86.95 ; P<0.01\right)$ all significantly decreased with increase in sampling time, while indole and octylaldehyde did not show variation with sampling time.

VOC Emission of T. pratense Under Field Conditions Under field conditions, eleven compounds were identified (Table 3), all of which were also detected in the laboratory. Levels of invertebrate herbivory measured as \% leaf area loss ranged from $3-15 \%$. Five compounds showed a significant response to herbivory in a multiple regression. The emission of $\alpha$-pinene $(T=4.06, P<0.01),(Z)-\beta$ ocimene $(T=5.21, P<0.01),(E)$ - $\beta$-ocimene $(T=4.63, P<$ $0.01)$, and nonanal $(T=2.86, P<0.05)$ declined with increased herbivory (Table 3 ), while decanal increased
( $T=2.3, P=0.04)$, and undecane and dodecane were not significantly influenced by herbivory. The compound DMNT also was negatively correlated with herbivory but the correlation was not significant $(T=2.1, P=0.6)$ There was no effect of herbivory on the emission of limonene and myrcene ( $T=1.9, P=0.2 ; T=1.6, P=0.2)$.

Effect of Temperature and Radiation Both radiation and temperature had significant effects on volatile emission in the field. An increase in radiation was negatively correlated with the emission of $(E)$ - $\beta$-ocimene and nonanal (Fig. 3A, $C)$, while $\alpha$-pinene and decanal emissions appeared to increase with radiation,. although this increase was not significant (Fig. 3B, D). Similarly, undecane and dodecane emission were not significantly influenced by radiation (results not shown). Elevated temperature enhanced the emission of ( $Z$ )-3-hexenyl acetate $(T=3.79, P<0.01), \alpha$ pinene $(T=3.15, p=0.02),(E)$ - $\beta$-ocimene $(T=3.05, P<$ $0.05)$, and $(Z)-\beta$-ocimene $(T=2.78, P<0.05)$. There were interactions between temperature and herbivory for $(E)$ - $\beta$ ocimene $(T=2.15, P<0.05)$ and between radiation and herbivory for $\alpha$-pinene $(T=4.06, P<0.05)$. (E)- $\beta$-Ocimene declined with an increase in herbivory at high temperature, while $\alpha$-pinene emission decreased with herbivory at low radiation.

Comparison of Laboratory and Field Experiments Comparing field and laboratory data, herbivore-induced compounds usually were detected in lower relative amounts (\% total compounds) in the field compared to the laboratory. The relative amounts of $(Z)-\beta$-ocimene and (E)- $\beta$-ocimene and limonene were lower in the field $(T=-2.9, P=0.01$; $T=-3.374, P<0.01$, and $T=-3.45, P<0.01$, respectively), while the amounts of $\alpha$-pinene, decanal, and undecane were higher $(T=3.35, P<0.01 ; T=2.09, P=0.05$, and $T=4.94, P<$ 0.01 , respectively). DMNT, nonanal, and (Z)-3-hexenyl acetate did not vary significantly in relative amount between field and laboratory conditions.

Principal components analysis of the relative amounts of volatiles emitted showed that the first axis (Principal factor 1) explained $60 \%$ of the variation in both field and laboratory experiments. The herbivore induced compounds, (Z)- $\beta$ ocimene and $(E)$ - $\beta$-ocimene, were positively correlated with this axis, while decanal and undecane were negatively correlated with this axis (Fig. 4). In the laboratory, the more heavily damaged plants ( $>10 \%$ leaf damage) were positively correlated with herbivore-induced compounds (Fig. 4A), while in the field experiment, the less damaged plants $(<10 \%$ leaf damage) were positively correlated with herbivoreinduced compounds (Fig. 4B).

For $(E)$ - $\beta$-ocimene, the dominant herbivore-induced compound in $T$. pratense, the proportion as a percentage of the total volatile blend generally increased with amount 
Fig. 3 Dependence of volatile emissions (ng $(\mathrm{g} \mathrm{DW})^{-1} \mathrm{~h}^{-1}$ ) from Trifolium pretense on radiation measured in the field experiment. (A) (E)- $\beta$-ocimene (B) $\alpha$-pinene, (C) nonanal, and (D) decanal
A)

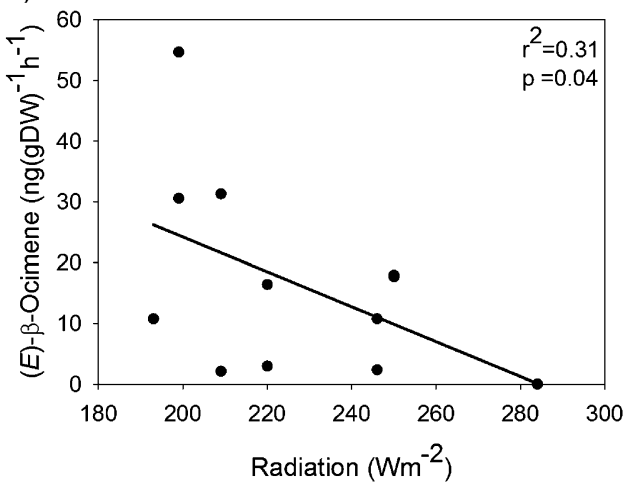

C)

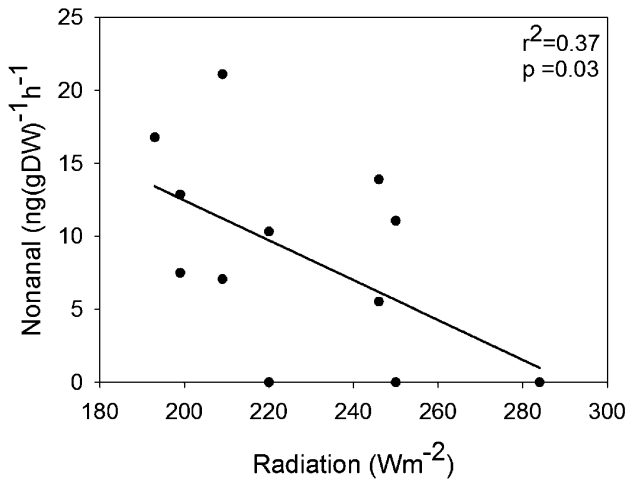

B)

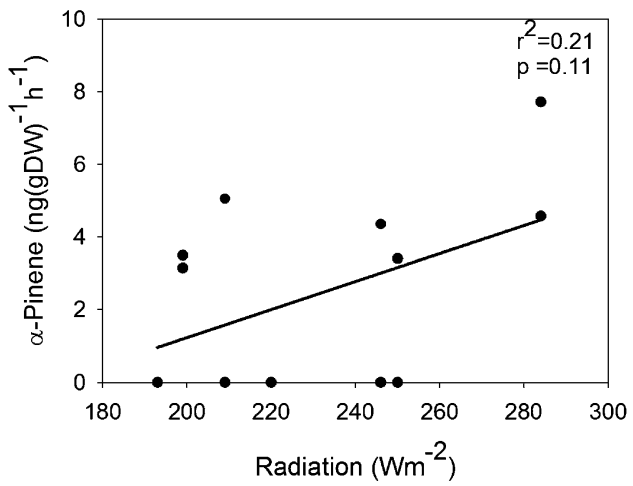

D)

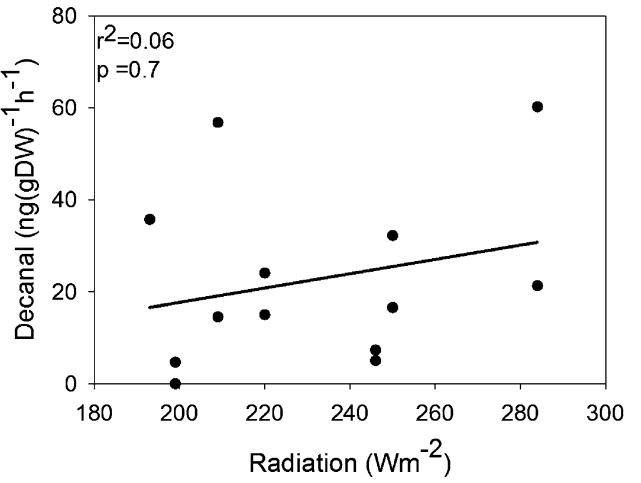

of damage under laboratory conditions (Fig. 5A), while in the field, intermediate levels of damage were associated with the greatest proportion of (E)- $\beta$-ocimene (Fig. 5B). To try and resolve this apparent contradiction, we reanalyzed the field emission data by removing the effects of radiation. (E)- $\beta$-Ocimene continued to show a decline with increased herbivory (Fig. 6A). Similarly, the emission of nonanal decreased with herbivory (Fig. 6C). However, amounts of $\alpha$-pinene showed no trend in this regard (Fig. 6B), while the amounts of decanal increased with herbivory (Fig. 6D).

\section{Discussion}

Trifolium pratense is cultivated as forage and is found growing wild in a variety of grassland and ruderal habitats. Here, we report on the volatile compounds emitted by $T$. pratense growing under laboratory and field conditions. In the laboratory, feeding by the generalist lepidopteran Spodoptera littoralis significantly increased the amount of volatile organic compounds (VOCs) released, while elevated temperature did not significantly influence total emission. The release of eight individual compounds was herbivore-induced, of which the major compound, the monoterpene $(E)$ - $\beta$-ocimene, made up $30-50 \%$ of the total. The other principal herbivore-induced plant volatiles (HIPVs) of this species were the isomeric monoterpene, $(Z)-\beta$ ocimene, the monoterpene linalool, the sesquiterpene $(E)$ - $\beta$-caryophyllene, the sesquiterpene-derived homoterpene 4,8-dimethyl-1,3,7-nonatriene (DMNT) and methyl salicylate. Only three of these HIPVs were detected in the field. Surprisingly, their emission did not increase in relation to an increase in naturally-occurring levels of invertebrate herbivory, but rather decreased. Temperature and radiation significantly influenced the emission of all volatiles in the field except the aliphatic hydrocarbons.

The VOCs of $T$. pratense also have been reported from other plant species. DMNT, for example, has been detected frequently as an HIPV from plant species, such as maize, cotton, and cabbage. Such widespread HIPVs are suggested to be useful in attracting generalist natural enemies of herbivores (Turlings et al. 1998; De Boer and Dicke 2004). However, the low abundance HIPV, 1-octen-3-ol, so far has been documented from only a few plant species, including Phaseolus lanatus (lima bean) Medicago truncatula, and Lotus japonicus (Arimura et al. 2000; Ozawa et al. 2000; Leitner et al. 2005), all of which belong to the family Fabaceae. Interestingly, high amounts of 1-octen-3-ol also have been reported from mushrooms where they have antifeeding effects on slugs (Wood et al. 2001). This compound could serve as an anti-feedant in $T$. pratense and other Fabaceae, but not much is known on the direct defense properties of HIPVs (Unsicker et al. 2009).

Among the volatiles of $T$. pratense are some that have been reported as HIPVs in other species, but were not induced in $T$. pratense. Indole, for example, was measured 

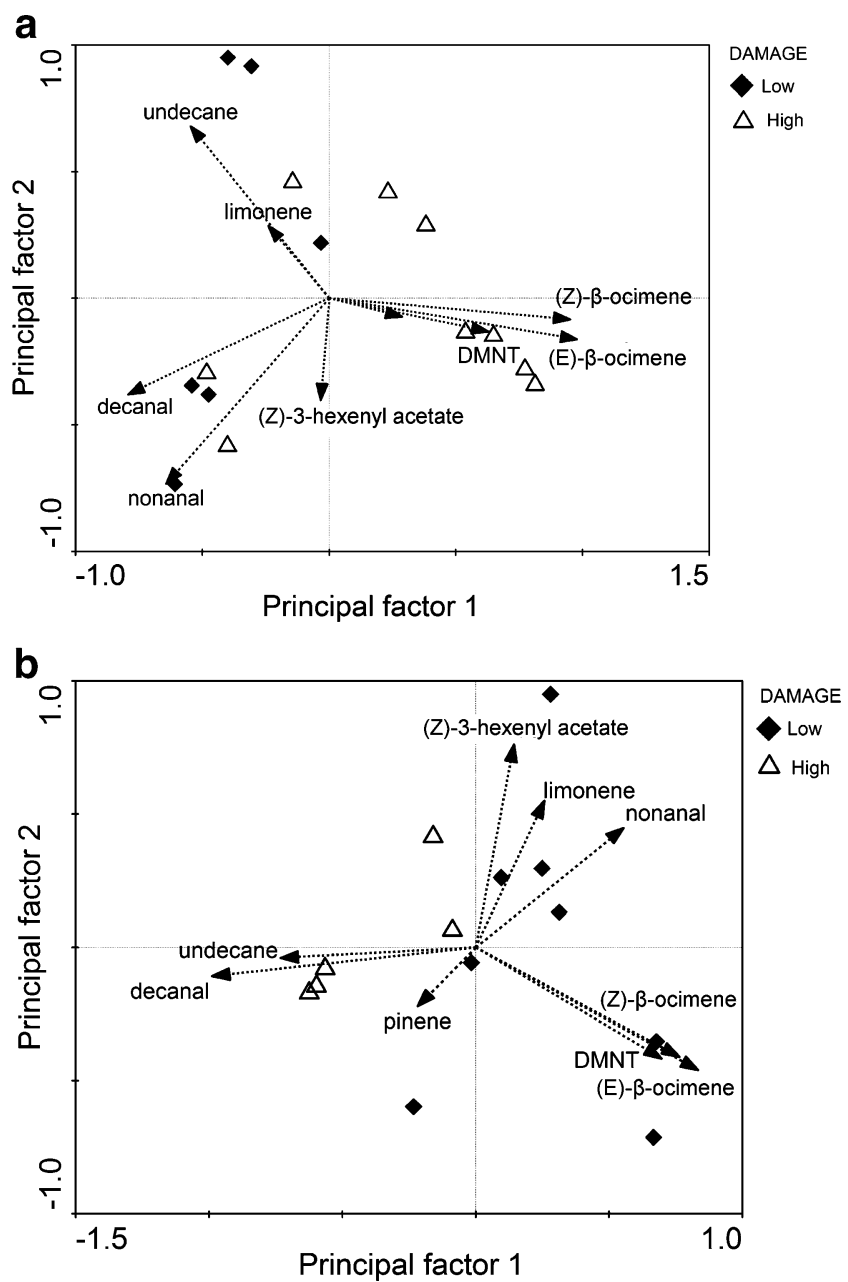

Fig. 4 Principal components analysis of the volatile emission of Trifolium pratense (A) in the laboratory experiment, and (B) in the field experiment based on the relative proportions of compounds in the headspace. Damage classes were allocated based on the percent damage to the leaf in both laboratory and field experiment. For the laboratory experiment, this ignored the effect of feeding duration. Damage was classified as high if it was more than $10 \%$. Compounds are represented by arrows, each pointing in the direction of greatest increase. Smaller angles between arrows show higher correlation. Plant samples are indicated by symbols. Samples that cluster together are highly correlated, and samples and arrows that are in the same area are also correlated

only after herbivore attack in cotton and maize (Röse and Tumlinson 2004) but was constitutively emitted by $T$. pratense. (Z)-Jasmone also was not significantly induced in T. pratense, though it has been reported to be induced by feeding or by applying oral secretions in Nicotiana attenuata, maize, and cotton (Loughrin et al. 1994; Lou and Baldwin 2003; Röse and Tumlinson 2004). Another important feature of the HIPV composition of $T$. pratense is the dominance of $(E)$ - $\beta$-ocimene $(30-50 \%$, Table 2$)$. In other plant species, other HIPVs dominate the odor bouquet. For example, $(E)$ - $\beta$-caryophyllene was the most dominant compound in several of the ecotypes of Datura wrightii in response to induction by methyl jasmonate or leaf beetle herbivory (Hare 2007), while (Z)- $\alpha$-bergamotene was the main volatile compound in Nicotiana attenuata (Halitschke et al. 2000). Thus, volatile bouquets often are species specific. In the case of $T$. pratense, specificity may arise from the mixture of certain widespread volatiles, such as $(E)$ - $\beta$-ocimene $(E)$ - $\beta$-caryophyllene, DMNT, linalool, and MeSA with the Fabaceae-specific 1-octen-3-ol.

Herbivore-induced volatiles usually are reported to be first emitted 12-24 h after herbivory (Turlings et al. 1998; Heil 2008). However, a very rapid response to herbivory was exhibited by $T$. pratense in the laboratory where the HIPVs (Z)- $\beta$-ocimene, $(E)$ - $\beta$ - ocimene, DMNT, and MeSA were detected in the first 45 minutes after feeding was initiated (Table 2). This rapid release may be relevant to the proposed role of volatiles as within-plant or between-plant signals (Karban et al. 2000; Kessler et al. 2006; Heil and Silva Bueno 2007). To date, only green-leaf volatiles (GLVs) and MeSA have been shown to induce chemical defenses when applied to plants (Heil and Silva Bueno 2007; Park et al. 2007; Kost and Heil 2008), but the role of terpenes like $(E)$ - $\beta$-ocimene needs further investigation in this regard (Gershenzon 2007). Besides the rapidly emitted compounds, $T$. pratense showed significant increases in the emission of some substances, including linalool, 1-octen-3ol, $(E)$ - $\beta$-caryophyllene, and $(E, E)-\alpha$-farnesene, only after the plants were exposed to herbivory for more than $2 \mathrm{~h}$. These compounds may be useful in attracting herbivore enemies, as has been shown for other species of plants, even though they are produced in relatively low amounts (less than $2 \mathrm{ng}$ leaf ${ }^{-1} \mathrm{~h}^{-1}$ ) (Table 2). Insects have been shown to detect relatively low amounts of VOCs, and higher emissions do not always correspond with increased response (Bruce et al. 2005).

There are only a few studies that directly compare herbivore-induced volatile production in the field and laboratory (Heil 2008; Dicke 2009). In our work, many compounds identified in the laboratory, such as indole, were not detected in the field. This discrepancy could be due to differences in growth conditions. Indole, for example, is often produced as a result of physiological stress (Dudareva et al. 2004). This compound may have been produced in the growth chamber used for the laboratory experiments, since many climate chambers are known to be oxygen-rich. Other compounds identified in laboratory collections, such as sabinene, 1,8-cineole, $\beta$ pinene, germacrene $\mathrm{D},(Z)$-jasmone $(E, E)$ - $\alpha$-farnesene, and (E)- $\beta$-farnesene, were not detected possibly due to the shorter collection time of $30 \mathrm{~min}$ used in the field. These compounds also were not detected under laboratory conditions within a 30 min collection. A short collection time was deemed necessary in the field to minimize physical stress on plants and to allow sampling of many plants. 
Fig. 5 Effect of herbivory on emission of $(E)$ - $\beta$-ocimene (expressed as percentage of total blend) from Trifolium pratense under (A) laboratory and (B) field conditions
A)

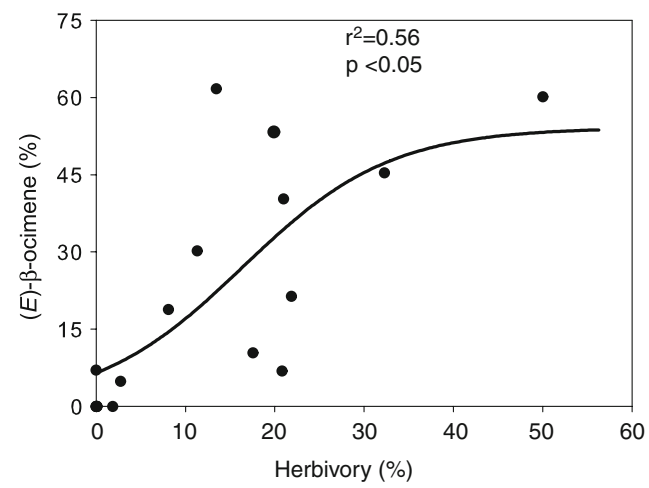

B)

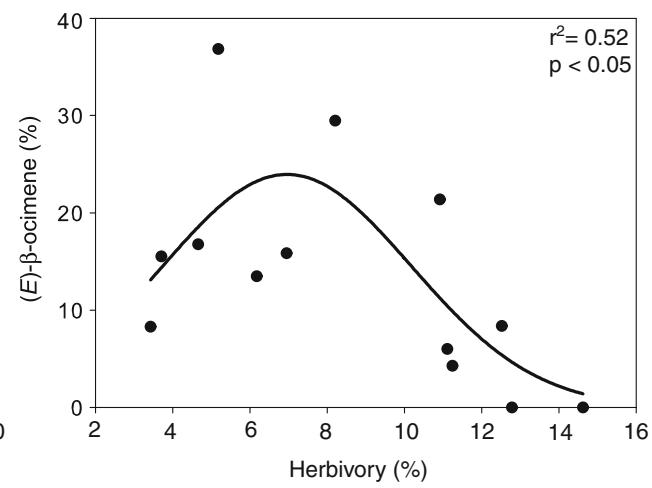

The differences in volatile composition observed between laboratory and field collections also might be attributed to differences in the apparatus used. Plants were enclosed in glass jars in the lab and in polyethylene terephthalate (PET) bags in the field. However, volatile recovery rates between glass vials and PET bags should not differ. Comparison of the recovery rates of VOCs from mixtures of standard compounds in glass vessels vs. PET bags showed no significant differences for limonene, linalool, MeSA, and (E)- $\beta$-caryophyllene (Stewart-Jones and Poppy 2006). Ambient air may contain ozone, which
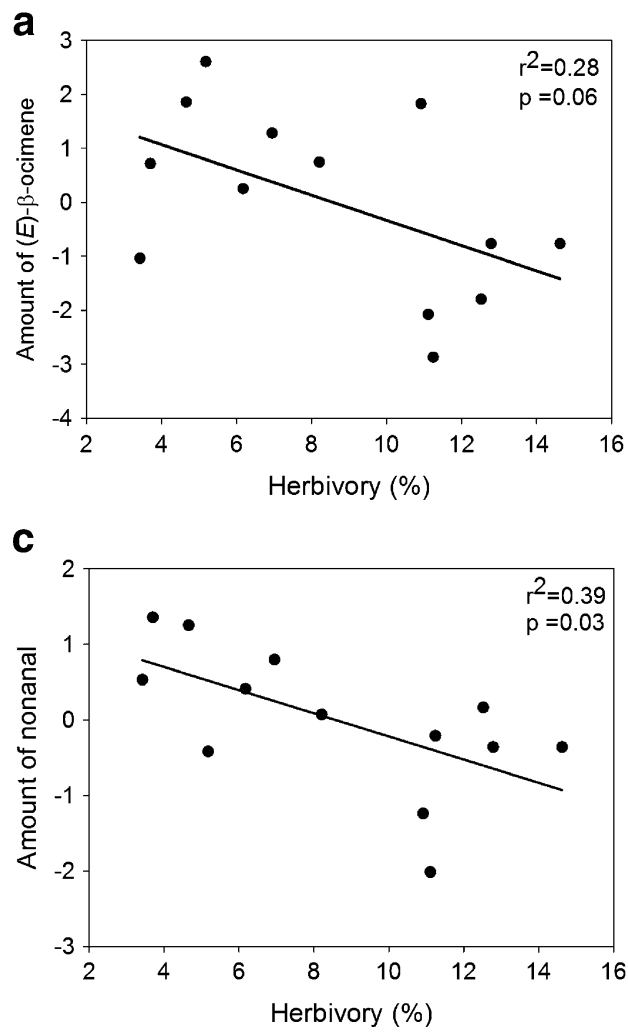

Fig. 6 Dependence of volatile emissions (ng $(\mathrm{g} \mathrm{DW})^{-1} \mathrm{~h}^{-1}$ ) from Trifolium pretense on measured herbivory rates in the field experiment. (A) (E)- $\beta$-ocimene, (B) $\alpha$-pinene, (C) nonanal, and (D) decanal breaks down many volatile compounds Pinto et al. (2007). Contamination of the airflow in the PET bags was avoided by using over-pressure push-pull system (Fig. 1).

The main cause of differences between field and laboratory volatile collections thus is likely to be differences in the environmental conditions, such as light, atmospheric composition, and water supply that plants were growing under, although it is difficult to identify specific factors without further investigation. A similar reduction in the number of volatile compounds detected under field conditions compared to controlled laboratory
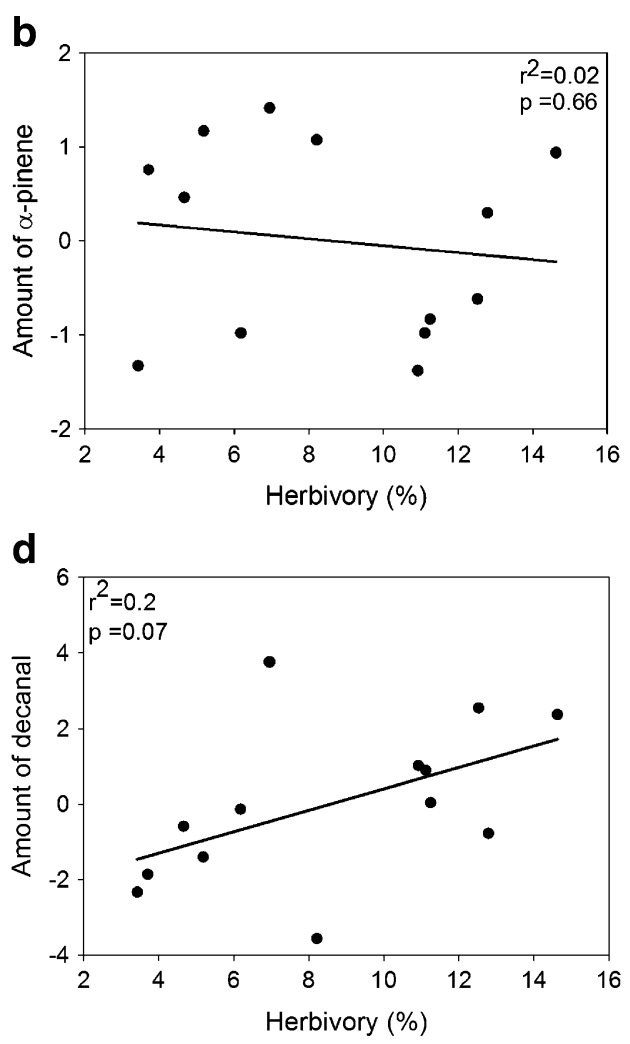

after removing the effect of radiation. Amount of each compound is expressed as a residual 
conditions also has been reported by Tooker et al. (2008) for Solidago altissima.

High levels of damage in the field were unexpectedly negatively correlated with herbivore-induced volatiles, unlike in the laboratory where damage led to an increase in volatile emission with eventual saturation (Table 3, Figs. 4 and 5). The plants selected for volatile collection in the field already had been damaged by herbivores at unknown time points prior to sampling, while in the laboratory induced volatile measurements were all performed within $24 \mathrm{~h}$ after herbivory was stopped. Laboratory measurements thus represent a snapshot taken right at the beginning of the time course of volatile emission following herbivory, while measurements in the field may have been made many days after herbivory.

The negative correlation of herbivory to volatile emission in the field (Fig. 4) also may be rationalized in several other ways. First, field plants that are attacked by herbivores may not allocate resources directly to defensive compounds, but to regrowth capabilities instead. T. pratense is a perennial plant that often behaves like a biennial with the ability to re-grow rapidly (Taylor and Quesenberry 1996). High herbivory may have induced a re-translocation of carbon and nitrogen to the roots in order to allow better re-growth in the later phases of development (Schwachtje and Baldwin 2008). Alternatively, resources that could have been invested in volatile formation instead may have been allocated to the formation of other chemical defenses. $T$. pratense has been shown to produce other secondary metabolites like clovamides in response to diseases or herbivory (Macfoy and Smith 1979; McMurchy and Higgins 1984; Tebayashi et al. 2000). Analysis of other induced defense compounds would provide more information on how this species responds in nature to herbivory.

Second, herbivory in the field may not be positively correlated to herbivory in the laboratory because of differences in the species of herbivore causing damage in the field as well as to the presence of pathogens. Different herbivores are known to induce different volatiles due to differences in elicitors present in their saliva (Turlings et al. 1993; Geervliet et al. 1997; De Moraes et al. 1998). For example, Geervliet et al. (1997) reported both qualitative and quantitative differences in the volatiles emitted by plants when fed on by two different caterpillar species. At the time of sampling in our study, the main observable herbivores on $T$. pratense were beetles and grasshoppers. Grasshoppers like the generalist species Chorthippus parallelus have also been shown to feed on Trifolium pratense in food choice experiments (Unsicker et al. 2008; Franzke et al. 2009). Grasshoppers contain different elicitors from S. littoralis (Alborn et al. 1997, 2007) that result in differences in the volatiles emitted by plants (Turlings et al. 1993). Since herbivory in the laboratory was induced with $S$ littoralis, the differences in herbivores in the field may have caused the differences in quality and quantity of the volatile blend. In addition, beetle larvae, which have been reported to feed on $T$. pratense roots (Tapia et al. 2007), may have affected volatile emission. Thus it is possible that the plant measured may have had beetle larvae feeding on the roots. Such multiple agents of herbivory, plus pathogen infestations, which were also observed in the field, may have altered and even suppressed VOC production (Maddox and Root 1990; Tooker et al. 2008).

A third reason why herbivory in the field might have been associated with lower volatile emission is that a lower level of emission may have resulted in fewer visits from natural enemies and thus a higher rate of herbivory (Halitschke et al. 2000; Heil 2008). Finally, our experimental plants in the field grew together with other species (Appendix 1), which may have influenced volatiles, although it is still unclear how species composition of communities affects volatile emission. However, other induced defense compounds are affected by neighboring species mainly through competitive interactions (Van Dam and Baldwin 2001; Marak et al. 2003; Barton and Bowers 2006). For example, Barton and Bowers (2006) reported an increase in iridoid glycosides in the presence of competitors, and this increase was dependent on neighbor identity.

The influence of temperature and radiation on the emission of specific volatiles was consistent with trends previously reported in the literature with elevated temperature and radiation generally increasing emission (Gouinguene and Turlings 2002; Kuhn et al. 2002; Blanch et al. 2007). Monoterpenes are especially light and temperature sensitive (Guenther et al. 1993; Kesselmeier and Staudt 1999). In the laboratory experiment, limonene, and the herbivore-induced compound $(E, E)-\alpha$-farnesene exhibited increased emission upon raising the temperature from $20^{\circ} \mathrm{C}$ to $30^{\circ} \mathrm{C}$ (Tables 1,2 , Fig 2). In the field, increased temperature was correlated with increased emission of (Z)-3-hexenyl acetate, and the terpenes, $(E)$ - $\beta$-ocimene, $(Z)-\beta$-ocimene, and $\alpha$-pinene, with the remainder of compounds showing no significant increases or decreases with temperature. Meanwhile, increased radiation in the field apparently correlated with increased $\alpha$-pinene and decanal but was not statistically significant, (Fig. 3). Counter to these trends, is the unexpected decline in the emission of the principal volatiles, $(E)-\beta$-ocimene and nonanal with increased radiation. This may have been due to the use of umbrellas for field collection on the warmer, sunny days. The resulting lower radiation on such days would be associated with higher temperatures, with the net result being a positive correlation between lower radiation and higher emission.

In summary, our results emphasize the need for caution in extrapolating the volatile emission profiles observed in laboratory experiments to plants growing in the field. Many of the compounds measured in the laboratory were not 
detected in the field, and many compounds observed to be induced by herbivory in the laboratory were not positively associated with herbivore damage in the field. The changes in light and temperature conditions between the lab and field could not account for these differences. Perhaps other abiotic factors not measured in this study were responsible for the variation, such as atmospheric gas composition, light quality, or water supply. Or, perhaps the combined influence of many biotic factors in the field, including multiple herbivores (both shoot and root), pathogens, and competing plants shape a vastly different emission profile. The damage observed in the field may have been too old to have an influence on volatile emission.

Future studies need to take into account biotic and abiotic factors that may influence emission in the field especially those, such as the presence of multiple herbivores and competing plants, which cannot be easily simulated in the laboratory. Such work preferably should manipulate herbivory directly on field-grown plants and use this as a basis to make comparisons with emission from plants with previously existing herbivore damage. More complete and accurate knowledge of the range of volatiles emitted from field plants is essential if we are to make progress in understanding the physiological and ecological functions of these compounds.

Acknowledgments We thank Daniel Veit who assisted in the design and construction of the field volatile collection system. Sylvia Creutzburg, Rebecca Wagner, Andreas Weber, and the gardeners of the MPICÖ assisted in various other aspects of this work. We also thank The Max Planck Society and the International Max Planck Research School for funding this project.

Open Access This article is distributed under the terms of the Creative Commons Attribution Noncommercial License which permits any noncommercial use, distribution, and reproduction in any medium, provided the original author(s) and source are credited.

\section{References}

Alborn, H. T., Hansen, T. V., Jones, T. H., Bennett, D. C., Tumlinson, J. H., Schmelz, E. A., and Teal, P. E. A. 2007. Disulfooxy fatty acids from the American bird grasshopper Schistocerca americana, elicitors of plant volatiles. Proc. Natl. Acad. Sci. U. S. A 104:12976-12981.

Alborn, T., Turlings, T. C. J., Jones, T. H., Stenhagen, G., LOUGHRIN, J. H., and TUMLINSON, J. H. 1997. An elicitor of plant volatiles from beet armyworm oral secretion. Science 276:945-949.

Andrews, M., Scholefield, D., AbBerton, M. T., Mckenzie, B. A., Hodge, S., and Raven, J. A. 2007. Use of white clover as an alternative to nitrogen fertiliser for dairy pastures in nitrate vulnerable zones in the UK: productivity, environmental impact and economic considerations. Ann. Appl. Biol. 151:11-23.

Arimura, G., Kost, C., and Boland, W. 2005. Herbivore-induced, indirect plant defences. Biochim. Biophys. Acta Mol. Cell Biol. Lipids 1734:91-111.

Arimura, G., Tashiro, K., Kuhara, S., Nishioka, T., OzaWa, R., and TAKABAYASHI, J. 2000. Gene responses in bean leaves induced by herbivory and by herbivore-induced volatiles. Biochem. Biophys. Res. Commun. 277:305-310.

BARTON, K. E. and Bowers, M. D. 2006. Neighbor species differentially alter resistance phenotypes in Plantago. Oecologia 150:442-452.

Blanch, J. S., Penuelas, J., and Llusia, J. 2007. Sensitivity of terpene emissions to drought and fertilization in terpene-storing Pinus halepensis and non-storing Quercus ilex. Physiol. Plant. 131:211-225.

Bruce, T. J. A., Wadhams, L. J., and Woodcock, C. M. 2005. Insect host location: a volatile situation. Trends Plant Sci. 10:269-274.

Chen, F., Tholl, D., D’auria, J. C., Farooq, A., Pichersky, E., and GERSHENZON, J. 2003. Biosynthesis and emission of terpenoid volatiles from Arabidopsis flowers. Plant Cell 15:481-494.

Crawley, M. J. 2007. The R Book. Wiley. Chichester, England

De Boer, J. G. and Dicke, M. 2004. The role of methyl salicylate in prey searching behavior of the predatory mite Phytoseiulus persimilis. J. Chem. Ecol. 30:255-271.

De Moraes, C. M., Lewis, W. J., Pare, P. W., Alborn, H. T., and TumLInson, J. H. 1998. Herbivore-infested plants selectively attract parasitoids. Nature. 393:570-573.

DiCKE, M. 2009. Behavioural and community ecology of plants that cry for help. Plant Cell Environ. 32:654-665.

Dicke, M., Agrawal, A. A., and Bruin, J. 2003. Plants talk, but are they deaf? Trends Plant Sci. 8:403-405.

Dudareva, N., Pichersky, E., and Gershenzon, J. 2004. Biochemistry of plant volatiles. Plant Physiol. 135:1893-1902.

Figueiredo, R., Rodrigues, A. I., and CostA, M. D. 2007. Volatile composition of red clover (Trifolium pratense L.) forages in Portugal: The influence of ripening stage and ensilage. Food Chem. 104:1445-1453.

FontanA, A., Reichelt, M., Hempel, S., Gershenzon, J., and UNSICKER, S. B., 2009. The effects of arbuscular mycorrhizal fungi on direct and indirect defense metabolites of Plantago lanceolata L. J. Chem. Ecol. 35: 833-843

Franzke, A., Unsicker, S. B., SPecht, J., KÖHLER, G., and WEISSER, W. W. 2009. Being a generalist herbivore in a diverse world: how do diets from different grasslands influence food plant selection and fitness of the grasshopper Chorthippus parallelus?. Ecol Entomol (accepted).

Geervliet, J. B. F., Posthumus, M. A., Vet, L. E. M., and Dicke, M. 1997. Comparative analysis of headspace volatiles from different caterpillar-infested or uninfested food plants of Pieris species. J. Chem. Ecol. 23:2935-2954.

GERSHENZON, J. 2007. Plant volatiles carry both public and private messages. Proc. Natl. Acad. Sci. U. S. A. 104:5257-5258.

GouinguenE, S. P. and TuRLingS, T. C. J. 2002. The effects of abiotic factors on induced volatile emissions in corn plants. Plant Physiol. 129:1296-1307.

Guenther, A. B., Zimmerman, P. R., Harley, P. C., Monson, R. K., and FALL, R. 1993. Isoprene and monoterpene emission rate variability-model evaluations and sensitivity analyses. J. Geophys. Res.-Atmos. 98:12609-12617.

HalitschKe, R., Kessler, A., Kahl, J., LorenZ, A., and BALDwin, I. T. 2000. Ecophysiological comparison of direct and indirect defenses in Nicotiana attenuata. Oecologia 124:408-417.

HARE, J. D. 2007. Variation in herbivore and methyl jasmonateinduced volatiles among genetic lines of Datura wrightii. J. Chem. Ecol. 33:2028-2043.

HEIL, M. 2004. Induction of two indirect defences benefits Lima bean (Phaseolus lunatus, Fabaceae) in nature. J. Ecol. 92:527-536.

HEIL, M. 2008. Indirect defence via tritrophic interactions. New Phytol. 178:41-61.

HeIL, M., and Silva BuENO, J. C. 2007. Within-plant signaling by volatiles leads to induction and priming of an indirect plant 
defense in nature. Proc. Natl. Acad. Sci. U. S. A. 104:54675472.

HoghJEnSEN, H., and SCHJOERRING, J. K. 1994. Measurement of biological dinitrogen fixation in grassland-comparison of the enriched n-15 dilution and the natural n-15 abundance methods at different nitrogen application rates and defoliation frequencies. Plant Soil. 166:153-163.

Holopainen, J. K. 2004. Multiple functions of inducible plant volatiles. Trends Plant Sci. 9:529-533.

Karban, R., BAldwin, I. T., BAXTer, K. J., Laue, G., and Felton, G. W. 2000. Communication between plants: induced resistance in wild tobacco plants following clipping of neighboring sagebrush. Oecologia 125:66-71.

Kesselmeier, J., and StaudT, M. 1999. Biogenic volatile organic compounds (VOC): An overview on emission, physiology and ecology. J. Atmos. Chem. 33:23-88.

Kessler, A., and BALDWIN, I. T. 2001. Defensive function of herbivore-induced plant volatile emissions in nature. Science 291:2141-2144.

Kessler, A., Halitschke, R., Diezel, C., and Baldwin, I. T. 2006. Priming of plant defense responses in nature by airborne signaling between Artemisia tridentata and Nicotiana attenuata. Oecologia 148:280-292.

Kost, C., and HeIL, M. 2005. Increased availability of extrafloral nectar reduces herbivory in Lima bean plants (Phaseolus lunatus., Fabaceae). Basic Appl. Ecol. 6:237-248.

Kost, C., and HeIL, M. 2008. The defensive role of volatile emission and extrafloral nectar secretion for lima bean in nature. J. Chem. Ecol. 34:2-13.

Kuhn, U., Rottenberger, S., Biesenthal, T., Wolf, A., Schebeske, G., Ciccioli, P., Brancaleoni, E., Frattoni, M., Tavares, T. M., and Kesselmeier, J. 2002. Isoprene and monoterpene emissions of Amazonian tree species during the wet season: Direct and indirect investigations on controlling environmental functions. J. Geophys. Res.-Atmos. 107:13.

Leitner, M., Boland, W., and Mithofer, A. 2005. Direct and indirect defences induced by piercing-sucking and chewing herbivores in Medicago truncatula. New Phytol. 167:597-606.

LOU, Y., and BALDWIN, I. T. 2003. Manduca sexta recognition and resistance among allopolyploid Nicotiana host plants. Proc. Natl. Acad. Sci. U. S. A. 100:14581-14586.

Loughrin, J. H., Manukian, A., Heath, R. R., Turlings, T. C. J., and Tumlinson, J. H. 1994. Diurnal cycle of emission of induced volatile terpenoids herbivore-injured cotton plants. Proc. Natl. Acad. Sci. U. S. A. 91:11836-11840.

MACFOY, C. A., and SMITH, I. M. 1979. Phytoalexin production and degradation in relation to resistance of clover leaves to Sclerotinia and Botrytis spp. Physiol. Plant. Pathol. 14:99-111.

MaddoX, G. D., and Root, R. B. 1990. Structure of the encounter between goldenrod (Solidago altissima) and its diverse insect fauna. Ecology 71:2115-2124.

MaraK, H. B., BIERE, A., and VAn Damme, J. M. M. 2003. Fitness costs of chemical defense in Plantago lanceolata L.: Effects of nutrient and competition stress. Evolution 57:2519-2530.

MCCLOUD, E. S., and BALDWIN, I. T. 1997. Herbivory and caterpillar regurgitants amplify the wound-induced increases in jasmonic acid but not nicotine in Nicotiana sylvestris. Planta 203:430 435

MCMURChY, R. A., and Higgins, V. J. 1984. Trifolirhizin and maackiain in red-clover - changes in Fusarium roseum avenaceum-infected roots and in vitro effects on the pathogen. Physiol. Plant. Pathol. 25:229-238.

Murray, P. J., Cheung, A. K. M., and AbBerton, M. T. 2007. Intraspecific variation in Trifolium pratense: impact on feeding and host location by Sitona lepidus (Coleoptera, Curculionidae). J. Pest Sci. 80:51-57.
Ozawa, R., Shimoda, T., KaWaguchi, M., Arimura, G., Horiuchi, J., NishioKA, T., and TAKABAYASHI, J. 2000. Lotus japonicus infested with herbivorous mites emits volatile compounds that attract predatory mites. J. Plant Res. 113:427-433.

Park, S. W., Kaimoyo, E., Kumar, D., Mosher, S., and Klessig, D. F. 2007. Methyl salicylate is a critical mobile signal for plant systemic acquired resistance. Science 318:113-116.

Pinto, D. M., Blande, J. D., Nykanen, R., Dong, W. X., NerG, A. M., and Holopainen, J. K. 2007. Ozone degrades common herbivore-induced plant volatiles: Does this affect herbivore prey location by predators and parasitoids? J. Chem. Ecol. 33: 683-694.

Roscher, C., Schumacher, J., BaAde, J., Wilcke, W., Gleixner, G., Weisser, W. W., Schmid, B., and Schulze, E. D. 2004. The role of biodiversity for element cycling and trophic interactions: an experimental approach in a grassland community. Basic Appl. Ecol. 5:107-121.

RöSE, U. S. R., and TumLinson, J. H. 2004. Volatiles released from cotton plants in response to Helicoverpa zea feeding damage on cotton flower buds. Planta 218:824-832.

Scherber, C., Mwangi, P. N., Temperton, V. M., Roscher, C., SCHUMACHER, J., SCHMID, B., and WeISSER, W. W. 2006. Effects of plant diversity on invertebrate herbivory in experimental grassland. Oecologia 147:489-500.

SCHWACHTJE, J., and BALDWIN, I. T. 2008. Why does herbivore attack reconfigure primary metabolism? Plant Physiol. 146:845-851.

Spehn, E. M., Scherer-Lorenzen, M., Schmid, B., Hector, A., Caldeira, M. C., Dimitrakopoulos, P. G., Finn, J. A., Jumpronen, A., O'Donnovan, G., Pereira, J. S., et al. 2002. The role of legumes as a component of biodiversity in a crossEuropean study of grassland biomass nitrogen. Oikos 98:205-218.

Stewart-Jones, A., and Poppy, G. M. 2006. Comparison of glass vessels and plastic bags for enclosing living plant parts for headspace analysis. J. Chem. Ecol. 32:845-864.

Tapia, S., Pardo, F., Perich, F., and Quiroz, A. 2005. Clover root borer Hylastinus obscurus (Marsham) (Coleoptera: Scolytidae) has no preference for volatiles from root extracts of disease infected red clover. Acta Agric. Scand. Sect. B-Soil Plant Sci. 55:158-160.

Tapia, T., Perich, F., Pardo, F., Palma, G., and Quiroz, A. 2007. Identification of volatiles from differently aged red clover (Trifolium pratense) root extracts and behavioural responses of clover root borer (Hylastinus obscurus) (Marsham) (Coleoptera : Scolytidae) to them. Biochem. Syst. Ecol. 35:61-67.

TAYLOR, N. L., and QUESENBERRY, K. H. 1996. Red Clover Science. Current Plant Sciences and Biology in Agriculture. Dordrecht: Kluwer Academic.

Tebayashi, S., Ishihara, A., TsudA, M., and Iwamura, H. 2000. Induction of clovamide by jasmonic acid in red clover. Phytochemistry 54:387-392.

Temperton, V. M., Mwangi, P. N., Scherer-Lorenzen, M., Schmid, B., and BuchmanN, N. 2007. Positive interactions between nitrogen-fixing legumes and four different neighbouring species in a biodiversity experiment. Oecologia 151:190-205.

Ter Braak, C. J. F., and Šmilauer, P. 2002. CANOCO Reference Manual and CanoDraw for Windows User's Guide: Software for Canonical Community Ordination (version 4.5). Microcomputer Power (Ithaca NY, USA), $500 \mathrm{pp}$.

Tholl, D., Boland, W., Hansel, A., Loreto, F., Röse, U. S. R., and SCHNitZLER, J. P. 2006. Practical approaches to plant volatile analysis. Plant $J$. 45:540-560.

ToOker, J. F., Rohr, J. R., Abrahamson, W. G., and De Moraes, C. M. 2008. Gall insects can avoid and alter indirect plant defenses. New Phytol. 178:657-671.

Turlings, T. C. J., Mccall, P. J., Alborn, H. T., and Tumlinson, J. H. 1993. An elicitor in caterpillar oral secretions that induces corn seedlings to emit chemical signals attractive to parasitic wasps. J. Chem. Ecol. 19:411-425. 
Turlings, T. C. J., Lengwiler, U. B., Bernasconi, M. L., and WeCHSLER, D. 1998. Timing of induced volatile emissions in maize seedlings. Planta 207:146-152.

Unsicker, S. B., BAer, N., Kahmen, A., Wagner, M., Buchmann, N., and WEISSER, W. W. 2006. Invertebrate herbivory along a gradient of plant species diversity in extensively managed grasslands. Oecologia 150:233-246.

Unsicker, S. B., Oswald, A., Kohler, G., and Weisser, W. W. 2008. Complementarity effects through dietary mixing enhance the performance of a generalist insect herbivore. Oecologia 156:313-324.
Unsicker, S. B., Kunert, G., and Gershenzon, J. 2009. Protective perfumes: the role of vegetative volatiles in plant defense against herbivores. Curr. Opin. Plant Biol. 12:479-485.

VAN Dam, N. M., and Baldwin, I. T. 2001. Competition mediates costs of jasmonate-induced defences, nitrogen acquisition and transgenerational plasticity in Nicotiana attenuata. Funct. Ecol. $15: 406-415$.

Wood, W. F., Archer, C. L., and LARgent, D. L. 2001. 1-Octen-3ol, a banana slug antifeedant from mushrooms. Biochem. Syst. Ecol. 29:531-533. 